Saudi Journal of Medicine

Abbreviated Key Title: Saudi J Med ISSN 2518-3389 (Print) |ISSN 2518-3397 (Online)

Original Research Article

\title{
A Study of Fetal Apgar score in Pregnancy beyond 40 Weeks
}

\author{
Dr. Ananth Pai
}

Associate Professor, Department of Paediatrics, Kanachur Institute of Medical Sciences, Mangalore-Thokkottu-Konaje University Rd, Kotekar Village, Deralakatte, Karnataka 575018, India

DOI: $10.36348 /$ sjm.2020.v05i04.003 $\quad$ | Received: 31.03.2020 | Accepted: 07.04.2020 | Published: 13.04 .2020

*Corresponding author: Dr. Ananth Pai

\section{Abstract}

Postdated pregnancy or in other words the pregnancy which has crossed the EDD is one of the many reasons that causes a great amount of stress to the parents and also the pediatricians. Prolongation of pregnancies complicates pregnancies and carries increased risk to mother and fetus. Emerging evidence demonstrates that the incidence of complications increases after 40 weeks of gestation. The present study conducted to find out the fetal outcome of such prolonged pregnancy. Methods: A prospective study conducted in Department of Pediatrics Kanachur Institute of Medical Sciences, Deralakatte, Mangalore, Karnataka. Data collected from pregnant women completed 40 week of gestational age admitted in hospital were collected. Aim of study is to know the fetal complications. Result: In our study out of 30 pregnant women were selected. Conclusion: Post term pregnancies require early detection, effective and proper planning management.

Keywords: Postdated pregancy, fetal complications.

Copyright @ 2020: This is an open-access article distributed under the terms of the Creative Commons Attribution license which permits unrestricted use, distribution, and reproduction in any medium for non-commercial use (NonCommercial, or CC-BY-NC) provided the original author and source are credited.

\section{INTRODUCTION}

Post dated pregnancy is defined as one which has crossed expected date of delivery. Pregnancy more than 42 weeks or 294 days is called post term pregnancy.

Prolongation of pregnancy complicates upto $10 \%$ of all pregnancies and carries increased risk to mother and fetus $[1,2]$. Post term perinatal mortality is greater than that of term pregnancy in almost all studies [3]. Post term is also associated with increased maternal morbidity [4]. Ante -partum stillbirth at and beyond term (37-43 weeks gestation) is a major public health problem accounting for a greater contribution to perinatal mortality than either deaths from complications of prematurity or the sudden infant death syndrome [5].

Exact etiology is not known but some risk factors are associated with postterm pregnancy like parity, maternal age, past history of postterm pregnancy, genetics and obesity $[6,7]$.

Common risk factors include primiparity [810], previous postterm pregnancy [11], male fetus [12], obesity [13], hormonal factors and genetic predisposition [14].
Post-term pregnancy associated with an increased risk of postnatal mortality and morbidity including meconium aspiratiom syndrom, oligohydramnios, macrosomia, fetalbirth injuries, septisemia, rate of non reassuring fetal heart rate, fetal distress in labour and maternal complication incresed c.s rate, cephalopelvic disproportion, cervical tear, dystocia, post partamhemorrhage [15].

In the present study, fetal outcome was studied in pregnancy beyond 40 weeks in consideration of spontaneous and induced labor

\section{METHODS}

A prospective study conducted in Department of Pediatrics Kanachur Institute of Medical Sciences, Deralakatte, Mangalore, Karnataka. Data collected from pregnant women completed 40 week of gestational age admitted in hospital were collectedrs. Aim of study is to know the APGAR score.

\section{Patient Selection}

By random selection fulfilling following criteria

- Those who crossed expected date of delivery

- Vertex presentation

- Surity of dates

- Singleton pregnancy 
Total 30 patients were selected according to the clinical examination of the patient.

\section{RESULT}

Table-1: Distribution of cases according to Parity

\begin{tabular}{|l|l|}
\hline Gravida & No. of patients \\
\hline Primi & 21 \\
\hline Multi & 09 \\
\hline
\end{tabular}

Table-2: Distribution of cases according to Gestational Age

\begin{tabular}{|l|l|}
\hline Gestational age & No. of patients \\
\hline$>40$ & 27 \\
\hline$>41$ & 3 \\
\hline
\end{tabular}

Table-3: Distribution of cases according to Age

\begin{tabular}{|l|l|}
\hline Age in years & No of patients \\
\hline$<20$ & 08 \\
\hline $21-30$ & 19 \\
\hline$>31$ & 03 \\
\hline
\end{tabular}

Table-4: Distribution of cases according to APGAR SCORE at $5 \mathrm{~min}$

\begin{tabular}{|l|l|}
\hline APGAR SCORE at 5 min & No of patients \\
\hline$<7$ & $26(18.5)$ \\
\hline$>7$ & $114(81.5)$ \\
\hline
\end{tabular}

\section{DISCUSSION}

The present study was conducted to find the maternal and perinatal morbidity associated with post dated pregnancy, total of 140 cases were post dated in 3 year period which are selected based on inclusion criteria.

Incidence of post dated pregnancy were more among primiparity, Olesen AW [10] in his study found that majority of postdated patients belong to primiparity.

Majority of patients were between 40-41 week in our study which correlates with Nikita Patel [16].

Majority of patients were more in age group 21-30 years, Beischer [17], Bancroft [18] in his study found that majority of postdated patients belonged to the age group 21-30 years.

A comparative study done by C.J.M Sneijers $e t$ al., shows $88.7 \%$ rate of induction in postterm pregnancy. Present study shows that percentage for type of induction for Cerviprime and misoprostol $(25 \mu \mathrm{g})$ was $85.7 \%$ and $14.3 \%$, a comparative study done by Ss Ramesh et al., shows $74.4 \%$ and $9.21 \%$ for Cerviprime, and misoprostol $(25 \mu \mathrm{g})$ respectively.

In the present study Mode of delivery are 60 $(42.85 \%)$ is normal vaginal delivery, 6(4.\%) are instrumental delivery, caesarean section in $74(52.85 \%)$ which correlates with study done by Farhat Naz/Amina Javid [19] shows that rate of LSCS, FTVD (spontaneous or induced) and Instrumentation was 70\%, $18.33 \%$ and $11.67 \%$ respectively. Study done by

Kana R Odedara [20] shows that rate of LSCS, FTVD (spontaneous or induced) was $62 \%$ and $38 \%$ respectively.

Most common indications for LSCS are fetal distress 22(30\%), MSL 15(20\%), failed induction $14(19 \%)$, severe oligohydromnios 10(13.5\%), CPD $7(9.5 \%)$, others are $6(8 \%)$, which correlates with Martin et al., [21] $31.6 \%$ and other studies James Alexander et al., [22] also showed fetal distress is most common indication for LSCS.

Majority of babies $114(81.5 \%)$ were having Apgar score $>7$. Singal P et al., [23], James Alexander et al., [22] and Heimstad R et al., 24 found similar results as present study.

\section{CONCLUSION}

Post term pregnancies require early detection, effective and proper planning management. With Regular antenatal check-up, incidence of postdate pregnancy can be decreased and it is important because of definite risk to fetus as pregnancy continuing beyond 40 weeks of gestation is associated with increased perinatal morbidity and mortality .

\section{REFERENCE}

1. Olesen, A. W., Westergaard, J. G., \& Olsen, J. (2003). Perinatal and maternal complications related to postterm delivery: a national registerbased study, 1978-1993. American journal of obstetrics and gynecology, 189(1), 222-227.

2. Norwitz, E. R., Snegovskikh, V. V., \& Caughey, A. B. (2007). Prolonged Pregnancy:: When Should We Intervene?. Clinical obstetrics and gynecology, 50(2), 547-557.

3. Vorherr, H. (1975). Placental insufficiency in relation to postterm pregnancy and fetal postmaturity: evaluation of fetoplacental function; management of the postterm gravida. American journal of obstetrics and gynecology, 123(1), 67103.

4. Caughey, A. B., Stotland, N. E., Washington, A. E., \& Escobar, G. J. (2007). Maternal and obstetric complications of pregnancy are associated with increasing gestational age at term. American journal of obstetrics and gynecology, 196(2), 155-e1.

5. Cotzias, C. S., Paterson-Brown, S., \& Fisk, N. M. (1999). Prospective risk of unexplained stillbirth in singleton pregnancies at term: population based analysis. Bmj, 319(7205), 287-288.

6. Divon, M. Y., Haglund, B., Nisell, H., Otterblad, P. O., \& Westgren, M. (1998). Fetal and neonatal mortality in the postterm pregnancy: the impact of 
gestational age and fetal growth restriction. American journal of obstetrics and gynecology, 178(4), 726-731.

7. Van Eyk, N., Allen, L. M., Sermer, M., \& Davis, V. J. (2000). Obstetric outcome of adolescent pregnancies. Journal of pediatric and adolescent gynecology, 13(2), 96.

8. Neilson, J. P. (2000). Ultrasound for fetal assessment in early pregnancy. Cochrane database Syst Rev, 2:Cd000182.

9. Taipale, P., \& Hiilesmaa, V. (2001). Predicting delivery date by ultrasound and last menstrual period in early gestation. Obstetrics \& Gynecology, 97(2), 189-194.

10. Olesen, A. W., Basso, O., \& Olsen, J. (1999). An estimate of the tendency to repeat postterm delivery. Epidemiology, 10(4), 468.

11. Mogren, I., Stenlund, H., \& Högberg, U. (1999). Recurrence of prolonged pregnancy. International journal of epidemiology, 28(2), 253-257.

12. Divon, M. Y., Ferber, A., Nisell, H., \& Westgren, M. (2002). Male gender predisposes to prolongation of pregnancy. American journal of obstetrics and gynecology, 187(4), 1081-1083.

13. Usha Kiran, T. S., Hemmadi, S., Bethel, J., \& Evans, J. (2005). Outcome of pregnancy in a woman with an increased body mass index. BJOG: an international journal of obstetrics \& gynaecology, 112(6), 768-772.

14. Laursen, M., Bille, C., Olesen, A. W., Hjelmborg, J., Skytthe, A., \& Christensen, K. (2004). Genetic influence on prolonged gestation: a populationbased Danish twin study. American journal of obstetrics and gynecology, 190(2), 489-494.

15. Cunningham, F. G., Leveno, K. J., Bloom, S. L., Hauth, J. C., Larry, C. G., \& Wenstrom, K. D. (2010). Post-term pregnancy. 23rd ed. In:
William's Obstetrics. New York: McGraw-Hill Companies; 832-841.

16. Nikita, P., \& Prerak, M. (2015). A Study of Maternal and Fetal Outcome in Postdate Pregnancy. IJSR. 78-96.

17. Beischer, N. A., Evans, J. H., \& Townsend, L. (1969). Studies in prolonged pregnancy: I. The incidence of prolonged pregnancy. American journal of obstetrics and gynecology, 103(4), 476482.

18. Bancroft-Livingston, G., \& Neill, D. W. (1957). Studies in prolonged pregnancy, Cord blood oxygen levels at delivery. Journal Obstet Gynecol, 64:498-503.

19. Farhat, N., Amina, J., Sara, S., Altaf, B., \& Amtullah, Z. (2009). Neonatal Outcome in Postterm Pregnancy.

20. Odedara, K. R., \& Kamaria, P. A. (2016). Post dated Pregnancy and its Maternal and Fetal Outcome. 15(9):24-25.

21. Martinb, C., De Paula., Marque, A. M., \& Silva, D. (1969). A clinical study of postdated pregnancy. International Journal of Reproduction, Contraception, Obstetrics and Gynecology, 56:830.

22. Macer, J. A., Macer, C. L., \& Chan, L. S. (1992). Elective induction versus spontaneous labor: a retrospective study of complications and outcome. American Journal of Obstetrics \& Gynecology, 166(6), 1690-1697.

23. Singal, P., \& Sharma, A. (2001). Fetomaternal outcome following postdate pregnancy-a prospective study. J Obst Gynecol of India, 51(5), 89-93.

24. Heimstad, R., Romundstad, P. R., Eik-Nes, S. H., \& Salvesen, K. A. (2006). Outcomes of pregnancy beyond 37 weeks of gestation. Obstetrics \& Gynecology, 108(3), 500-508. 